\title{
Language Learning Exposure and Grammatical Proficiency of Intermediate Pupils
}

\author{
Marz Kimberly T. Salas ${ }^{1}$ and Ma. Judy B. Legaspi ${ }^{2}$ \\ ${ }^{1}$ St. Scholastica's Academy, Bacolod City, Philippines \\ ${ }^{2}$ University of Negros Occidental-Recoletos, Bacolod City, Philippines
}

\begin{tabular}{l} 
Article history \\
Submitted: 22 October 2020 \\
Revised: 5 November 2020 \\
Accepted: 12 November 2020 \\
\hline Keywords \\
Language Education \\
Language Learning Exposure \\
Grammatical Proficiency \\
Intermediate Pupils \\
Descriptive-Correlational \\
Bacolod City
\end{tabular}

Introduction. The Philippines is recognized globally as one of the largest English-speaking nations. The majority of its population has at least some degree of fluency in the language. Filipinos are exposed to the heavy usage of English, not just in school but also in their everyday lives. Exposing elementary pupils to different language learning sources (home, friends, school, and media) can help them acquire the language more easily. Thus, the second-language acquisition is a holistic process, which means acquiring the second language is not confined within the four walls of the classroom. This paper describes the extent of language learning exposure and the level of grammatical proficiency of Grade 6 pupils of a Catholic school in Bacolod City. Similarly, it explores the difference in the pupils' extent of language learning exposure and level of grammatical proficiency. Also, it determines the relationship between language learning exposure and grammatical proficiency.

Methods. A descriptive-comparative and correlational research design were used to compare and correlate language learning exposure and grammatical proficiency of Grade 6 pupils of a Catholic school in Bacolod City during the School Year 2019-2020. Using stratified random sampling, 137 Grade 6 pupils served as respondents in the study. The current study employed an adapted survey questionnaire to assess the extent of language learning exposure and a standardized instrument to determine the level of grammatical proficiency of Grade 6 pupils to gather data for this study. Mean, Standard Deviation, Mann Whitney $\mathrm{U}$ test, and Spearman rank correlation was employed for the data analysis.

Results. The findings of the study revealed that the extent of language learning exposure of Grade 6 pupils is great, whereas the level of grammatical proficiency of Grade 6 pupils is below average. In relation to the problems of the study, no significant difference is found in the extent of language learning exposure of Grade 6 pupils when grouped according to sex and section. Furthermore, there is no significant difference in grammatical proficiency level when Grade 6 pupils are grouped according to sex. However, a significant difference is present in the level of grammatical proficiency when the pupils are classified according to section. Also, there is a correlation that exists between language learning exposure and grammatical proficiency which is inconclusive.

Conclusion. It is indicated that even when the Grade 6 pupils experience difficulties acquiring the second language, they can cope with these difficulties if they are sufficiently exposed to a languagerich environment where correct grammar is being modeled in oral and written production. Moreover, informal contexts and casual interactions should be considered to maximize the learner's exposure to the grammatical use of the language. Other possible factors, such as age, aptitude, motivation, attitude, personality, cognitive style, memory, and learning strategies, also affect the result. Enriching the different lessons and activities in English instruction and creating new instructional strategies to make language learning meaningful may be considered to effectively address the learners' needs in learning the second language.

Practical Value of the Paper. The present study significantly contributes to the few existing studies on the language learning exposure and grammatical proficiency of intermediate pupils. It is one of the first studies done in the University to identify the influence of specific factors like home, friends, 
school, and media on language learning exposure. The study also encourages other researchers to conduct studies related to the quality of language learning exposure and quality of grammar lessons and investigate grammatical proficiency further in other contexts to enrich more the literature and find solutions to the problems in the field of language proficiency. Also, the findings of the study provide baseline information in formulating an instructional program, which is the Grammatical Proficiency Enhancement Program, designed to improve the grammatical proficiency of the Grade 6 pupils by integrating the different dimensions of language learning exposure.

\section{References}

Aguilar, M., Bayot, R., Eusebio, J. P., Solis, N. M., Villaruel, J., \& Yu, S. H. (2013). Factors affecting the English proficiency of the elementary pupils at Central Philippine University. Academia. Retrieved from https:// www.academia. edu/8761470.

Al Zoubi, S. (2018). The impact of exposure to the English language on language acquisition. Journal of Applied Linguistics and Language Research, 5(4), 151-162. Retrieved from https://www.researchgate.net/ publication/328492845.

Alvarez, E. H. (2017). Enhancing the grammar competence of the senior secondary students through Communicative Language Teaching (CLT). International Journal of Research in Humanities and Social Studies, 4, 9-16.

Barraquio, D. C. (2015). Grammar proficiency of Colegio de San Juan de Letran Calamba college students. Philippine E-Journals.

Candilas, K. (2016). Language exposures: Determinants of English-speaking proficiency. Journal of English Language and Literature, 3(3). Retrieved from https://www.academia.edu/28751482/Language_Exposures_ Determinants_of_English_Speaking_Proficiency.

De Carvalho, M., Magno, C., Lajom, J., Regodon, J., \& Bunagan, K. (2011). Factors involved in the use of language learning strategies and oral proficiency among Taiwanese students in Taiwan and the Philippines. Asia-Pacific Education Researcher, 203, 489-502.

Leyaley, R. V. (2016). The English language proficiency of freshmen students in the institute of teacher education, Kalinga-Apayao State College. International Journal of Advanced Research in Management and Social Sciences.

Magno, C. (2009). Assessing the level of English language exposure of Taiwanese college students in Taiwan and the Philippines. The Asian EFL Journal Quarterly, 11(1).

Magpayo, C. B., Paras, R. D., \& Sarmiento, N. P. (2015). Grammatical competence of the first-year English major students of the teacher education department in Holy Angel University A.Y. 2014-2015: An Assessment. Academia. Retrieved from https://www.academia.edu/36609309.

Pascual, L. (2017). Exposure to English linguistic environment and oral proficiency of first year college students in Davao Del Norte. International Journal of Advancements in Research and Technology, 6(1). Retrieved from www.ijoart. Org/docs/EXPOSURE-TO-ENGLISH-LINGUISTIC-ENVIRONMENT-AND-ORAL-PROFICIENCY-OFFIRST-YEAR-COLLEGE-STUDENTS-IN-DAVAO-DEL-NORTE.pdf.

\section{Correspondence:}

Marz Kimberly T. Salas [marzsalas17@gmail.com] https://orcid.org/0000-0002-0411-0536 